This chapter focuses on what liberal arts students should learn, given the future they face, and how educational experiences can provide opportunities for that learning to take place. Mentoring is an important means by which a faculty member can promote effective learning.

\title{
Teaching Key Competencies in Liberal Arts Education
}

\author{
Edie N. Goldenberg
}

What do liberal arts students need to learn? That question has captured the time and energy of academics and others for more than a century, and there is no single generally accepted answer in sight. Nor should there be. One's answer depends on one's view of what a liberal arts education is meant to achieve and one's guess about what life for today's students will be like in the coming decades. In this chapter, I reflect upon my experience as dean for nine years of a large liberal arts college engaged in seriously rethinking undergraduate education within an even larger research university. First, I address three questions:

1. Why study the liberal arts?

2. What challenges will our students face in the future?

3. What do those challenges imply for today's educational programs in the liberal arts?

Then I conclude with some thoughts as I return to the faculty and become personally reinvolved in the world of classroom teaching.

\section{Why Study the Liberal Arts?}

A liberal arts education is a meaningful introduction to fundamental questions, ideas, and methods in several fields of inquiry and an intensive introduction to at least one field, the major. In order to provide sufficient breadth, the several fields normally include exposure to the humanities, sciences, and social sciences. A liberal arts degree does not signify training for 
employment in any immediate sense, even as it is widely recognized as an excellent foundation for a multitude of job opportunities and for graduate and professional study.

More than ever before, a liberal arts education is of special value today. A successful liberal arts experience can be a source of personal satisfaction for students throughout their lives. It has staying power beyond the short half-life of technical training because it introduces students to fundamental issues as they have been explored by others through the ages. A liberal arts major should provide exposure to ideas, feelings, and situations that are common to human experience and to the ways that respected minds and revered hearts have dealt with them. Through the mentoring process, faculty in the liberal arts deepen this exposure and help students relate it to their own futures.

The goals of a liberal arts education are to provide students with a solid foundation for problem solving; to help them understand others and interact effectively with them; to help students examine their own assumptions and avoid being taken in by specious argument; to help students feel connected with others who have dealt with similar feelings or situations or problems; to open students' eyes and minds to the fascinations of other cultures and experiences; to provide a deeper sense of self and citizenship, and to develop valued employees, responsible citizens, and effective leaders. Inside and outside the classroom, liberal arts students should learn how to learn and develop a zest for learning that will last them a lifetime.

Liberal arts students study what physicists or philosophers or poets or psychologists think about, how they go about their deliberations, and how they decide what they do and don't know. Students who are fortunate enough to study with active scholars learn how to learn from those who are lifetime experts at learning. In this way, students are exposed to what others regard as questions worth asking and goals worth pursuing. The faculty mentor is a role model and guide. In an ideal liberal arts setting, students learn to consider assertions critically, to decide what evidence deserves attention and what can be dismissed, and to distinguish careful arguments from sloppy ones. In my view, this is the heart of a liberal arts education: developing critical thinking skills and the ability to apply them to observations, arguments, and conclusions, thereby becoming less bound by one's own prejudices and rationalizations. Provided by the teacher and mentor, a quality liberal arts education helps students develop a proper balance between openness to new ideas and a healthy skepticism of those same ideas, a balance that permits knowledge to advance today and to continue to advance tomorrow.

Students learn in the classroom, of course, but they also can learn a great deal in less-formal settings from faculty and other mentors. The undergraduate research experience provides an ideal opportunity for researchoriented faculty to become effective mentors. The faculty member is comfortable in research situations; the student benefits from individualized coaching on everything from problem definition to data gathering to analy- 
sis to the ethical dilemmas in research. Research experiences work most powerfully when a faculty member and a student apprentice interact frequently and easily enough for the relationship to broaden to include academic advising and career counseling.

Achieving for the student a desirable blend of solid grounding in a field of study and broad exposure to multiple fields occupies academics as we design and redesign college curricula and create new learning experiences outside the classroom. Our tinkering never stops because students' needs change over time and because in their undergraduate years students cannot possibly learn all, or even most, of what they will need to know. Of course students need to learn computational, observational, and communication skills, but skills are not enough. With skills, they may be well trained, but to be well educated, they need to know how to continue learning long after they leave campus, and most of their later learning will occur outside of formal classroom settings.

Whether we achieve our ideals in liberal arts education is an empirical question that remains largely unanswered. For institutions of learning, universities are shockingly remiss when it comes to careful study of the effectiveness of their own educational programs. And even those general research findings that provide important insights into students' learning are often ignored. Nonetheless, periodic reexamination of our ideals is a worthwhile exercise in that it forces faculty to break out of habit, try to forecast as well as we can what our students will face in their futures, and rethink and occasionally redesign the learning environments we offer.

What faculty do spend a great deal of time and effort on is periodic debate over the appropriate content of course requirements. Much of the controversy over appropriate curricular content in the liberal arts swirls around departments of literature and history. Some people apparently include only the humanities and the social sciences in their definitions of the liberal arts. Mathematics and science are, have been, and continue to be important parts of a liberal arts education. Universities began recognizing this by the mid-1800s when presidents added science to literary departments. The "newcomers" to the liberal arts are not the sciences but rather fine arts, music, and the social sciences (Bordin, 1967; Peckham, 1967). If students are to be educated in a broad range of the liberal arts, we need to encourage nonscience majors to learn some science. We also need to relax the rigidity of some of our science concentrations to allow students to study the humanities and social sciences and to participate in the creative arts and overseas study.

\section{What Will the Future Hold for Our Students?}

We can observe features of U.S. society today that carry implications for how we educate our undergraduates, and we can make some informed guesses about the future. Today is a time of complex problems and dazzlingly rapid 
change. On the one hand, complexity encourages more and more specialization-more detailed study of smaller and smaller parts of problems. On the other hand, complexity means that understanding and solving problems often require broader knowledge than any single person commands. That is why teamwork has become so highly valued in the workplace. Real problems are multifaceted. They do not sort themselves neatly into disciplinary boxes. They are seldom exclusively political or ethical or economic or technical, but often all of the above. Problem solvers who are too specialized cannot be effective. They need to understand links across fields and they need to be able to cooperate with others who bring needed complementary expertise to the problem-solving mix.

Complexity drives the need for well-educated workers. Fewer and fewer jobs with reasonable wages can be performed adequately by people who lack reading, writing, arithmetic, reasoning, and communication skills. For the first time in history, a majority of new jobs in the United States require postsecondary education (Johnston and Packer, 1987). People will change jobs and occupations more frequently than before, making broad education and widely applicable skills even more important to a student's future.

Moreover, employees are working with a more diverse set of coworkers than in the past. Only 15 percent of new entrants to the labor force over the 1990s were native white males, as compared to 47 percent in 1987 (Johnston and Packer, 1987). Effectiveness in the workplace today requires communicating clearly and interacting with a demographically diverse set of coworkers. That will become even more important in the future.

The complexity of public problems also drives the need for a bettereducated voting public. Many policy domains such as national defense, the economy, pollution, or public health are highly technical. Arguments about choices cite scientific evidence at a time when national studies (Fox, 1999) express alarm at the shortages of science and math teachers and the poor preparation of U.S. students in science. Science and math literacy, too, will become more and more important over time.

In this context, citizens and leaders need education that is both broad and deep. The problems at the top of our agenda change quickly. Many we hear about now-for example, AIDS, global warming, U.S. policy toward a united Germany-were not even on most agendas fifteen years ago. Our leaders should be well prepared to address a wide variety of problems, including new ones as they emerge, and to recognize and understand their interconnectedness. Effective leaders must also be capable of building coalitions and motivating people of widely different backgrounds and experiences. This requires breadth and problem-solving skills, preparation for a wide variety of roles and situations, and understanding of different approaches and perspectives.

With the help of the faculty mentor, students need to develop their individual skills and much more. They also need to know how to identify 
which questions are worth asking, which problems can be solved with current tools and approaches, which goals are worth pursuing. We look to our citizens and leaders to choose goals wisely. We expect our leaders to motivate other individuals and organizations to behave in ways that further those goals, and to do so in the midst of constraints and opportunities that constantly impinge on the individuals and organizations they lead.

Effective individuals learn to operate through large-scale, complex institutions that are a fact of life in business, government, the courts, the media, hospitals, universities, and even U.S. charitable foundations. As Max Weber (1947) observed, these inventions of the twentieth century are superb vehicles for efficiently coordinating the efforts of many people as they pursue organizational goals. Bureaucracies have their advantages but they can also hamper adaptability, creativity, individuality, and renewal. Once set, bureaucratic rules can take on lives of their own, sometimes working mindlessly to produce undesirable and unintended results. Our students need to learn to see the whole and not only the efficiently operating parts. To succeed in most walks of life, they will need the skills to move large organizations in positive directions. That is no small task. As he thought about the ingredients necessary for effective leadership, John Gardner (1988) cited the ability to work with and through large complex organized institutions as the "single most important feature of 20th century leadership." Surely that will remain a reality in the twenty-first century as well. An education well-grounded in the liberal arts is one way for students to begin to acquire the breadth of knowledge necessary to be effective in large institutions.

Given the dizzying pace of change, the complexity of problems, the growing diversity of the population, and the reality of large organizations, academics need to think carefully once again about the central elements of a liberal arts education.

\section{What Are Key Competencies in the Liberal Arts Today?}

The literature on student learning dates back to the nineteenth century. The evidence is compelling that students learn more when they are engaged and involved, they learn more when they cooperate with each other, and the quality of teaching affects what students learn (Astin, 1993; Pascarella and Terenzini, 1991; Johnson, Johnson, and Smith, 1991). Yet faculty members are often slow to adjust their classroom approaches and routines and may overlook out-of-class mentoring opportunities. The time is ripe to pay more attention to the evidence we have on student learning - to design courses that actively involve students in their own learning and to design cooperative learning experiences. The reengagement of senior faculty in first- and second-year seminars is a positive step, especially if these seminars stimulate active in-class participation and significant self-directed (with faculty guidance) student projects. Undergraduate research experiences are also 
wonderful opportunities for student engagement in original discovery and cooperative learning.

At the University of Michigan we have found research experiences to be especially valuable in the sophomore year and additionally valuable to upper-class undergraduate and graduate mentors of the sophomore researchers (Nagda and others, 1998). The focus on cooperative problem solving in calculus and chemistry instruction is yet another positive step (Ewing, 1999; Ege, Coppola, and Lawton, 1997; Coppola, Ege, and Lawton, 1997). In the humanities and the social sciences, exposure to writings by and about people from other cultures helps students understand different perspectives and practices. There is something quite powerful in having students of different backgrounds engage each other in structured conversations around topics that bring out their different perspectives. The dialogue groups at Michigan are wonderful vehicles for fostering constructive conversations (Schoem, Frankel, Zuniga, and Lewis, 1993). These are all examples of faculty-led educational efforts in the liberal arts that take advantage of what we know about student learning and what we believe are important societal trends as we help students build competencies that will be important all though their lives. But even more needs to be done.

Another widely accepted finding about student learning is that students learn more when their extracurricular activities reinforce what they study in their classes (Astin, 1993). Yet a recent report of a survey of three hundred colleges and universities concludes that an "invisible wall separates academic life from the nonacademic side of college, a division reinforced on many campuses by separate administrative structures that seldom intersect" (Gaff, 1991, p. 129). As university presidents have become personally committed to improving undergraduate education and stemming the flow of criticism of the academy, the matter of how we teach and how students learn has been elevated to a level on campus that can bring classroom and nonclassroom activity together. The growth of living-learning programs on many campuses is a testament to that, as are the growth in research opportunities for undergraduates on and off campus and the growth in community service as part of in-class experiences. Administrators and faculty members can work together to enhance the mentoring options available to undergraduates.

Improvements are possible and clearly necessary in the way we approach a liberal arts education, but how are we to achieve them? One observer suggested that "the progress of an institution . . will be directly proportional to the death rate of the faculty" (Rudolph, 1977, p. 17), but surely that is excessively cynical. Clark Kerr (1982) noted that the two great periods of change in U.S. higher education-the 1870s and the 1960swere both periods of rapid enrollment growth and addition of new faculty and programs. Now we are faced with the challenge of changing in desirable ways during an extended period of no or slow growth. 
The obvious place to start is with the faculty. Liberal arts education today is well served by a faculty active in research. Who can better communicate the ways to learn and the commitment to learn for life than a faculty comprising people who chose to pursue careers of learning? They are living, breathing models of learning for life. When students work closely with faculty who are active in research, the students can experience learning with its highs and lows, from tedious attention to detail to the excitement of a new insight. They can see how an expert works with objects or people or experiments or texts. They can learn a great deal about the importance of integrity in learning and sharing what one learns with others. This is a not a unidirectional benefit. Research-active faculty members gain too from their exposure to undergraduates who ask for simple explanations, who ask naive questions about why particular questions are important, and who remind senior faculty members of the thrill that comes to a beginner who experiences the "aha" of discovery and understanding. Perhaps that is why over 90 percent of the Michigan faculty who have volunteered to work with first- or second-year students in research volunteer again the following year.

\section{Thoughts to Guide My Reentry as an Undergraduate Teacher and Mentor}

During my nine years as dean, I stepped out of a classroom teaching role in political science and public policy into what became my own mid-career liberal arts education with outstanding faculty in the humanities, sciences, and social sciences. My perspective will never be the same. As I reenter my professorial role and the classroom, I do so differently than before. These are a few of the lessons I have learned and the steps I now remind myself to take.

- Tell students why I think a question is important and show them how I approach answering it, giving them a sense of the blind alleys of inquiry as well as the neatness and logic of the solution. Students benefit from learning what we do and how we think even if they have no inclination to become professional academics themselves.

- Design learning opportunities that encourage undergraduates to work with each other and learn from each other.

- Construct some examples from other fields, with the help of my colleagues, and compare how similar questions are asked and answered in my field with how they are asked and answered in others.

- Call on a colleague in another department or a professional school to come talk with undergraduates about why learning in my field is important, and (of course) reciprocate if asked.

- Work closely with a few undergraduate students on my research or on designing class assignments or a course, and allow these experiences to develop into broader advising and mentoring relationships. 
- Find ways for more senior students to be trained to mentor first- and secondyear students. This benefits both the mentors and those being mentored.

- Ask the residence halls, the film society, or student clubs to plan programs that complement the topics covered in my course.

- Work with colleagues to design careful evaluations of teaching innovations.

- Enjoy my students. Let them experience the joy of discovery and remind me of just how exciting it was for me when I was just a beginner.

The liberal arts have never been more important than they are now in this age of information and rapid change. In their classrooms, their laboratories, and their lives, faculty mentors are in a wonderful position to help students become well educated and better prepared for their futures. Research-active faculty from all over the university can make a significant difference if they are willing to engage undergraduate students in actively creative endeavors. Working with students in this way brings joy to the learning experience for students and faculty too.

\section{References}

Astin, A. W. What Matters in College? Four Critical Years Revisited. San Francisco: JosseyBass, 1993.

Bordin, R. The University of Michigan: A Pictorial History. Ann Arbor: The University of Michigan Press, 1967.

Coppola, B. P., Ege, S. N., and Lawton, R. G. "The University of Michigan Undergraduate Chemistry Curriculum.2. Instructional Strategies and Assessment." Journal of Chemical Education, 1997, 74, 84-94.

Ege, S. N., Coppola, B. P., and Lawton, R. G. "The University of Michigan Undergraduate Chemistry Curriculum.1. Philosophy, Curriculum, and the Nature of Change." Journal of Chemical Education, 1997, 74, 74-83.

Ewing, J. (ed.). Towards Excellence: Leading a Doctoral Mathematics Department in the 21st Century. Providence, R.I.: American Mathematical Society Task Force on Excellence, 1999.

Fox, M. A. (chair). Transforming Undergraduate Education in Science, Mathematics, Engineering, and Technology. Committee on Undergraduate Science Education, National Research Council, Washington, D.C., 1999.

Gaff, J. New Life for the College Curriculum: Assessing Achievements and Furthering Progress in the Reform of General Education. San Francisco: Jossey-Bass, 1991.

Gardner, J. W. The Changing Nature of Leadership. Leadership Papers/11, July 1988, 3-24. Johnson, D. W., Johnson, P. T., and Smith, K. A. Cooperative Learning, ASHE-ERIC Higher Education Report No. 4. Washington, D.C.: Association for the Study of Higher Education and The George Washington University, 1991.

Johnston, W. B., and Packer, A. H. Workforce 2000: Work and Workers for the 21st Century. Indianapolis: Hudson Institute, 1987.

Kerr, C. "Postscript 1982: The Uses of the University Two Decades Later." Change, Sept./Oct. 1982, 14, 23-31.

Nagda, B. A., Gregerman, S. R., Jonides, J., von Hippel, W., and Lerner, J. S., "Undergraduate Student-Faculty Research Partnerships Affect Student Retention." The Review of Higher Education, Fall 1998, 22(1), 55-72. 
Pascarella, E. T., and Terenzini, P. T. How College Affects Students: Findings and Insights from Twenty Years of Research. San Francisco: Jossey-Bass, 1991.

Peckham, H. The Making of the University of Michigan, 1817-1967. Ann Arbor: The University of Michigan Press, 1967.

Rudolph, F. "Frames of Reference." Curriculum: A History of the Undergraduate Course of Study Since 1636. San Francisco: Jossey-Bass, 1977, 1-24.

Schoem, D., Frankel, L., Zuniga, X., and Lewis, E. A. Multicultural Teaching in the University. Westport, Conn.: Praeger, 1993.

Weber, M. Theory of Economic and Social Organization. (A. M. Henderson and T. Parsons, trans.). Glencoe, Ill.: Free Press, 1947.

Edie N. Goldenberg is professor of political science and public policy at the University of Michigan in Ann Arbor. She was dean of the College of Literature, Science and the Arts at Michigan from 1989 through 1998. 
